\title{
The secondary dispersion halos of platinum group elements and rare elements in rocks of the Vysotsky ore occurrence, Svetloborsky massif, Middle Urals
}

\author{
V.S. Nikiforova \\ Engineer, Department of geology of oil and gas, Saint Petersburg, Mining University, Saint Petersburg, \\ Russia \\ I.V. Talovina \\ Professor, Head of the Hystorical and dynamic geology department, Mining University, Saint-Petersburg, \\ Russia \\ G. Heide \\ Professor, Institutsdirektor, Technische Universität Bergakademie Freiberg, Freiberg, Germany
}

\begin{abstract}
Geological searches for secondary dispersion halos have important practical search value in areas with lack of exposure. In weakly exposed areas with a loose cover thickness of 0.2-10 m, testing is carried out using secondary dispersion halos - i.e. on the surface of eluvium, deluvium or the bottoms of a loose incision. The Svetloborsky duniteclinopyroxenite zonal massif, like other massifs of the Ural Platinum belt, is characterized by a rather closed inaccessible territory, partially covered by a cover of quaternary sediments with a thickness of up to $10 \mathrm{~m}$, in some areas - up to $25 \mathrm{~m}$. Also, almost complete absence of chromite schlieres is characteristic of the Svetloborsky massif, which are usually a clear visual sign of the presence of platinum-metal mineralization. Therefore, when conducting search operations within the massif, in addition to direct ore testing of bedrock and weathering crust, a lithogeochemical survey was carried out and the contents of platinum, palladium, gold and rare elements in secondary dispersion halos were determined.
\end{abstract}

Keywords: secondary dispersion halos, platinum group elements, rare elements, lithogeochemical survey, dunite, vein rocks, the Svetloborsky massif, the Ural Platinum belt

\section{INTRODUCTION}

The territory of the Svetloborsky massif is almost completely covered by a continuous cover of quaternary sediments, the thickness of which is 2-10 m, and in some areas the weathering crusts of dunites up to $25 \mathrm{~m}$ thick are developed, which greatly complicates the exploration work. In addition, the dunites of the massif are characterized by an almost complete absence of chromite schlieres, which are in other massifs of the Platinum belt of the Urals, for example, in Nizhny Tagil massif, a clear visual sign of the presence of platinum metal mineralization (Ivanov, 1997). Therefore, in addition to direct ore testing of bedrock, on the territory of the Svetloborsky massif, a lithogeochemical survey was carried out for the first time for the platinum-bearing mineralization of the Urals for the search for radical platinum-ore mineralization, according to the results of which the mineralized occurrence zone of Vysotsky was identified (Tolstykh et al., 2011, 2015).

Lithogeochemical work on the Svetloborsky massif was carried out by CJSC Ural-MPG in the period 2006-2009 in order to determine the contents of platinum, palladium, gold and a number of related elements, testing was carried out on a exploration network. 


\section{METHODOLOGY}

Within the central part of the Svetloborsky massif lithogeochemical survey using secondary halos showed only isolated abnormal samples, so it was necessary to identify anomalies extension exploration network and a re-sampling. In the central part of the Svetloborsky massif, the processes of recrystallization of dunites are developed, so the chromite formations and platinum are distributed extremely unevenly, therefore, lithogeochemistry can be effective only with a frequent sampling network.

During sampling, loose clay and sand-clay eluvial-deluvial material was selected from a subsoil layer weighing 200-300 g along a $200 \times 40$ m network with a network thickening in separate, most abnormal areas, to a cell size of $100 \times 40 \mathrm{~m}$. Separate profiles laid at a distance of $400 \mathrm{~m}$ from each other, they cross the massif, capturing not only the dunites of the massif core, but also the clinopyroxenites of the massif shell (Nikiforova et al., 2016).

During lithogeochemical survey, 1163 samples were obtained, of which 171 were taken directly at the Vysotsky ore occurrence. The sample processing process included drying the sampled material, sifting through an 80 mesh sieve, attritioning to $0.074 \mathrm{~mm}$, quarrying of the sample to obtain two batches weighing about 100-150 g. These samples were analyzed for the content of Pt, Pd, Au by an assay in a Lakefield laboratory (South Africa) and spectral analysis for a number of rare elements in OJSC Ural Central Laboratory. In interpreting the sampling data for secondary halos for a more detailed study, the Vysotsky ore occurrence site was selected, characterized by the wide development of dike and vein rocks.

Processing and interpretation of the initial geochemical data was carried out by methods of mathematical statistics using modern software, including the programs Statistica 12.6 and Surfer 15.0. The data obtained as a result of the analyzes were used to study the distribution characteristics of precious metals and rare elements in eluvial and deluvial-eluvial deposits.

\section{RESULTS AND DISCUSSION}

Table 1 presents the average contents of $\mathrm{Pt}, \mathrm{Pd}, \mathrm{Au}$ and rare elements in eluvial and deluvialeluvial deposits in comparison with the geochemical background calculated for the Svetloborsky massif. The geochemical background was calculated from 848 analyzes; the background concentrations of chemical elements were calculated as median values in the sample.

According to Table 1, for the eluvial and deluvial-eluvial deposits of the Vysotsky ore occurrence, elevated levels of platinum, palladium, chromium, manganese, nickel are characteristic, lower - barium, strontium and phosphorus, the content of other chemical elements (silver, cobalt, vanadium, titanium, copper, zinc, lead in the secondary halos of the Vysotsky ore occurrence are comparable with the geochemical background calculated for the Svetloborsky massif.

Among the group of precious metals, platinum has a maximum average content of $0.5 \mathrm{ppm}$, palladium $-0.08 \mathrm{ppm}$ and gold $-0.06 \mathrm{ppm}$. The $\mathrm{Pt} / \mathrm{Pd}$ ratio varies from 2 to 15 , in some cases reaching $30-50$, which is quite comparable with the data on the primary dunites of the Svetloborsky massif.

Most of the elements of the iron group are characterized by a relatively uniform distribution. Nickel contents vary from 7 to $150 \mathrm{ppm}$, cobalt from 2 to $70 \mathrm{ppm}$, manganese 70-600 ppm, with

Table 1. Average contents of $\mathrm{Pt}, \mathrm{Pd}, \mathrm{Au}$ and rare elements in eluvial and deluvial-eluvial deposits of the Vysotsky ore occurrence, $\mathrm{ppm}$.

\begin{tabular}{lllllllllllllll}
\hline Element & $\mathrm{Pt}$ & $\mathrm{Pd}$ & $\mathrm{Au}$ & $\mathrm{Ag}$ & $\mathrm{Cr}$ & $\mathrm{Mn}$ & $\mathrm{Ni}$ & $\mathrm{Co}$ & $\mathrm{V}$ & $\mathrm{Ti}$ & $\mathrm{Zn}$ & $\mathrm{Ba}$ & $\mathrm{Sr}$ & $\mathrm{Pb}$ \\
\hline $\begin{array}{l}\text { Vysotsky ore } \\
\text { occurrence }\end{array}$ & 0,05 & 0,01 & $<0,02$ & 0,01 & 600 & 250 & 60 & 10 & 17 & 600 & 7 & 50 & 1 & 0,9 \\
$\begin{array}{l}\text { Geochemical } \\
\text { background }\end{array}$ & 0,03 & $<0,02$ & $<0,02$ & 0,01 & 500 & 180 & 30 & 9 & 18 & 600 & 9 & 65 & 10 & 1 \\
\hline
\end{tabular}


the exception of several samples with contents of 700-900 ppm, vanadium 18-50 ppm, in single samples - more than $200 \mathrm{ppm}$. Chromium in samples from Vysotsky ore occurrence is characterized by a less uniform distribution with a change in contents from 30 to $1000 \mathrm{ppm}$, on average 600 ppm. It should be noted that, unlike the whole array, samples with high chromium content do not always correspond to samples with high platinum content. Cobalt content also varies from 2 to 70 ppm, titanium - from 60 to $1000 \mathrm{ppm}$. Cobalt content also varies from 2 to $70 \mathrm{ppm}$, titanium from 60 to $1000 \mathrm{ppm}$.

Transit elements in the eluvial-deluvial deposits of the Svetloborsky massif are characterized by an uneven distribution. Copper and phosphorus are contained in the initial samples in an amount of from 0.1 to $18 \mathrm{ppm}$ and from 7 to $180 \mathrm{ppm}$, respectively. Lead and zinc are characterized by maximums of 4 and $20 \mathrm{ppm}$. The analyzed large-ion lithophilic elements reach maxima of $100 \mathrm{ppm}$ (barium) and $60 \mathrm{ppm}$ (strontium).

Based on the calculation results for all the studied chemical elements, maps were constructed with the image of the positive and negative anomalies of the element contents (Figures 1-4). Maps of anomalies of elements within the entire Svetloborsky massif are presented in (Gayfutdinova et al. 2015), and in this work refined detailed maps of
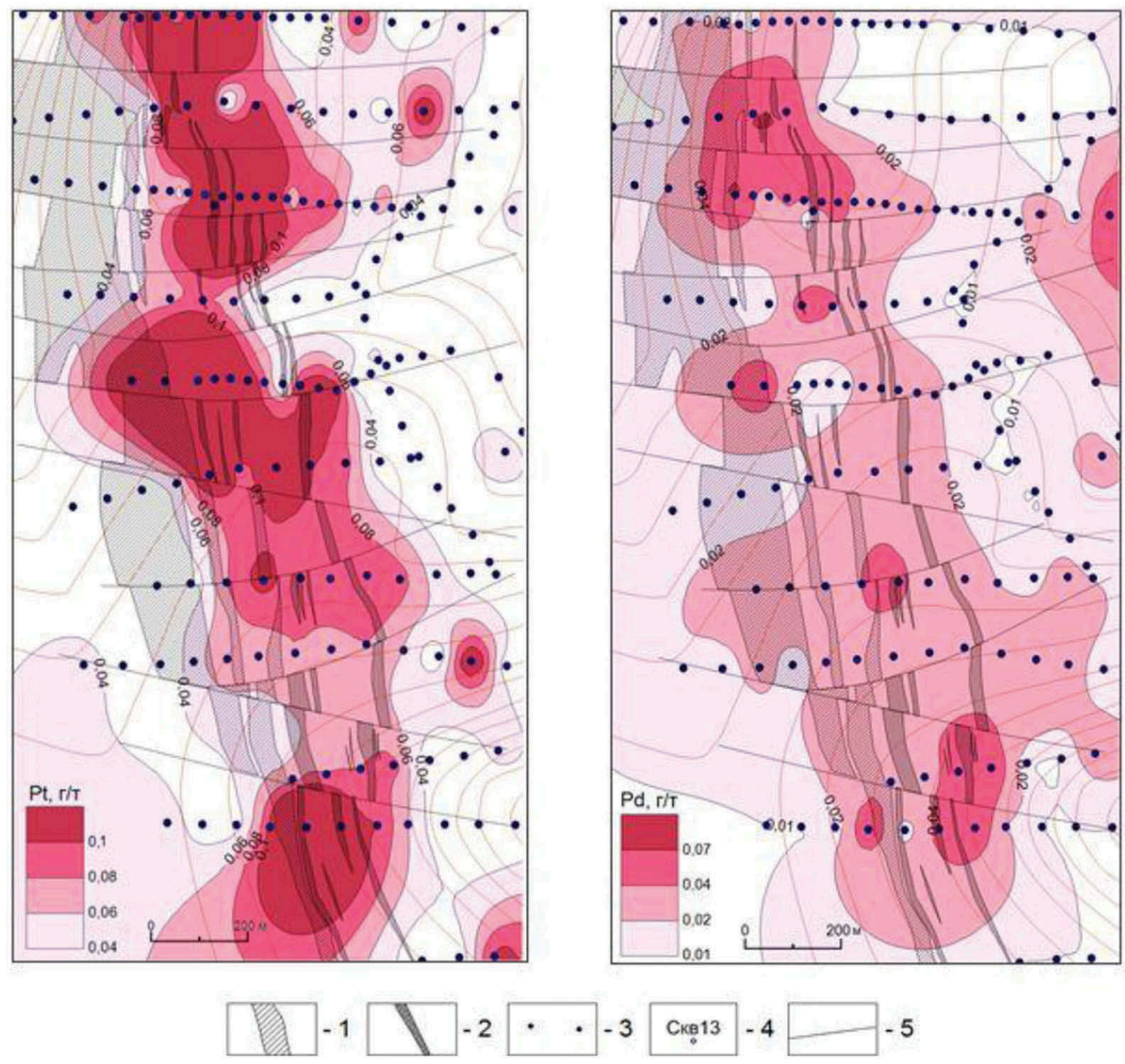

Figure 1. Secondary halos of dispersion of platinum and palladium.

1 - clinopyroxenite shell, 2 - hornblendite and diopside rock dikes, 3 - sampling points, 4 - wells, 5 - tectonic disturbances. 

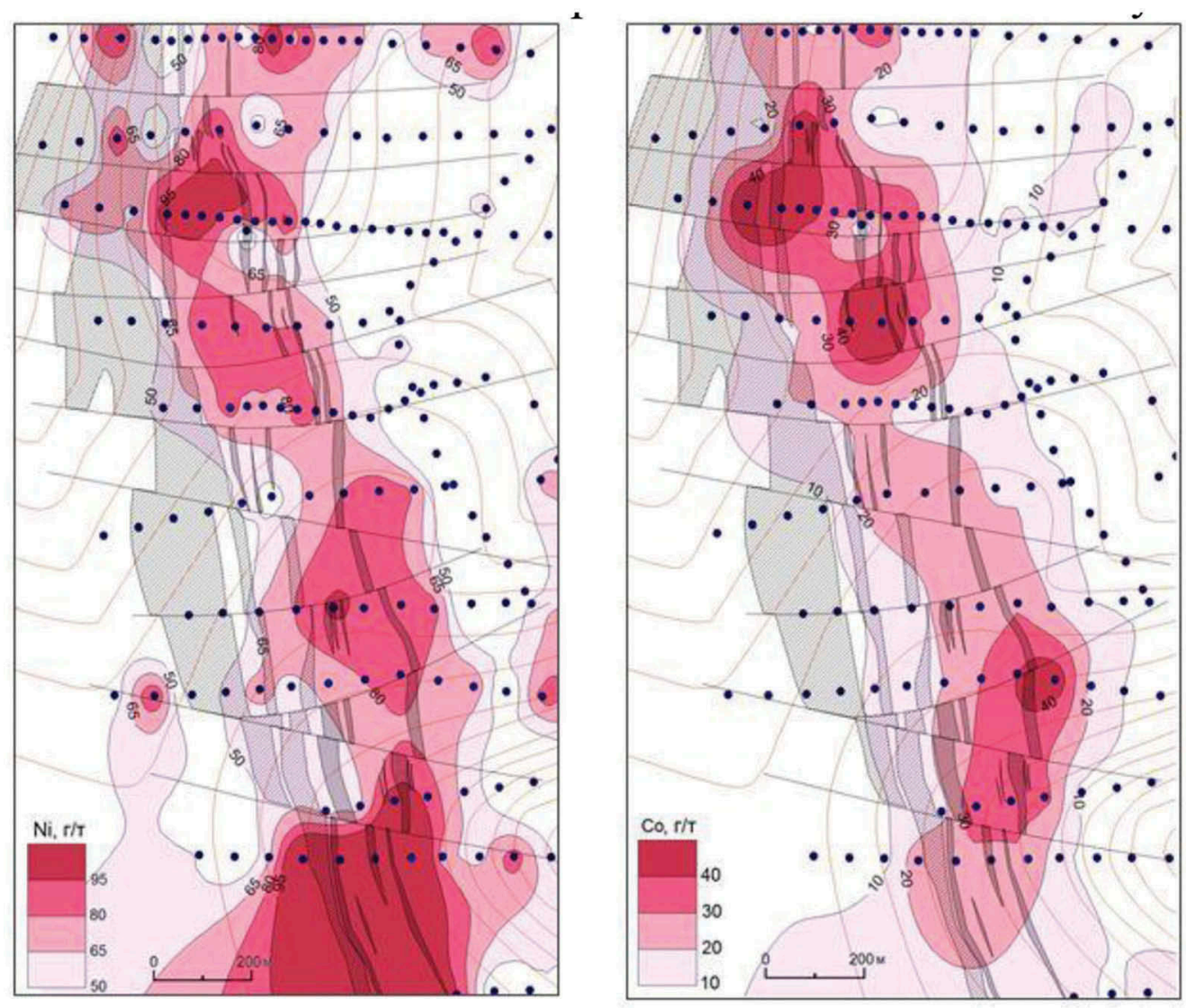

Figure 2. Secondary halos of dispersion of nickel and cobalt.

anomalies within the western contact of the massif, to which the Vysotsky ore occurrence is confined, are given.

\subsection{Platinum and palladium}

Within the Vysotsky ore occurrence platinum and palladium in secondary halos, several closely related positive elongated anomalies form (Figure 1).

The length of the platinum and palladium anomalies is from 400 to $900 \mathrm{~m}$, with an average width of about $400 \mathrm{~m}$. The platinum and palladium contents within the northern and southern positive anomalies exceed $0.23 \mathrm{ppm} 0.04 \mathrm{ppm}$, respectively, which is higher than the platinum and palladium in anomalies within the entire array.

As was shown by us in (Gayfutdinova et al. 2015), the platinum anomalies are generally confined to the western boundary of the dunite core of the massif in the zone of contact with the clinopyroxenite shell in the region of development of recrystallized medium- and coarsegrained dunites of the core center and fine-grained peripheral dunites. The construction of anomaly maps on the scale of Vysotsky's ore occurrence also revealed the spatial confinement of platinum and palladium anomalies to the areas of development of vein hornblendites and diopsides and their conformity to each other.

Despite the fact that the level of platinum content in scattering halos is relatively low, the shape of the anomalies and their confinement to the fields of development of dyke rocks, as well as to certain petrographic varieties of primary dunites, suggests a regular nature of their 

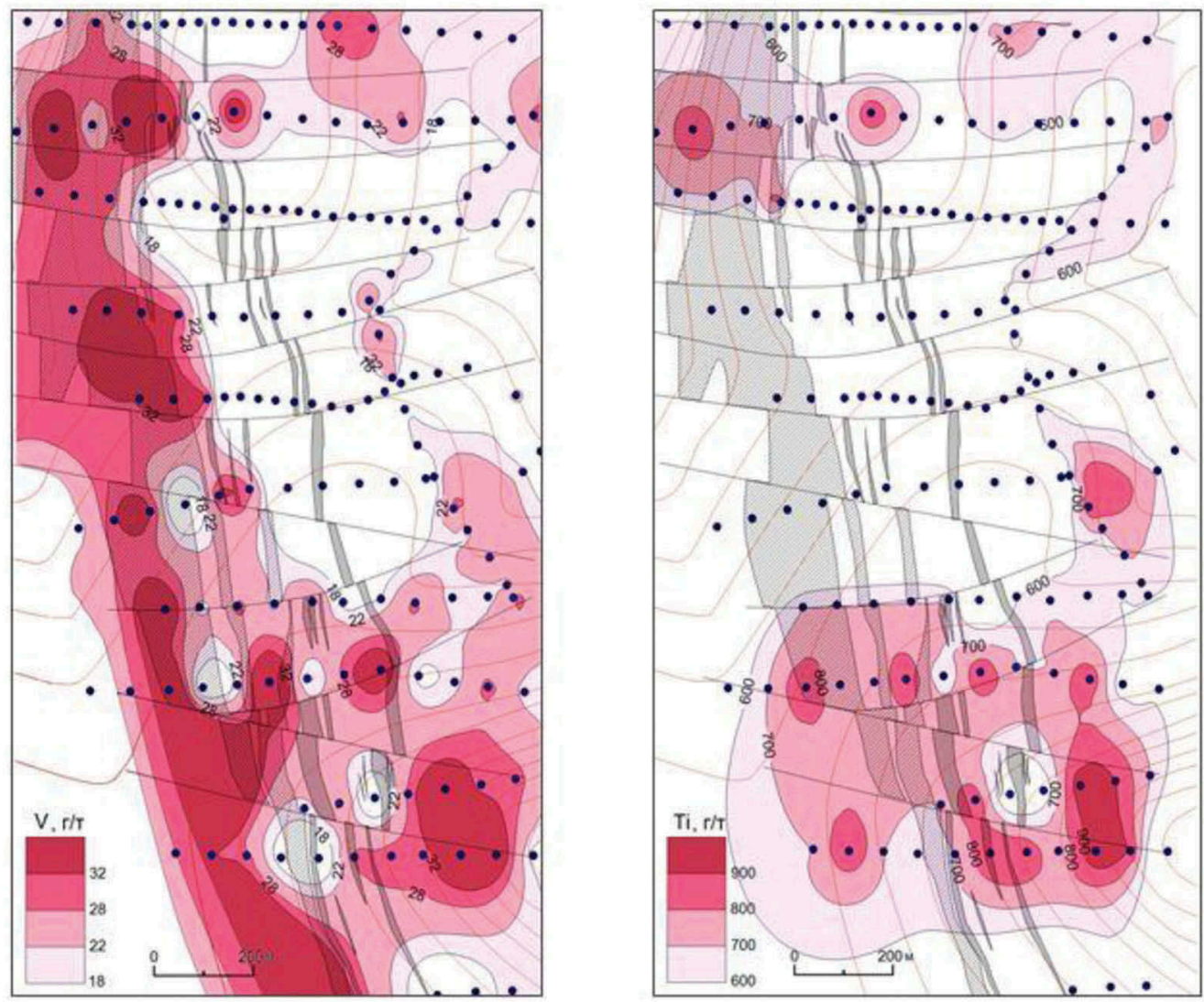

Figure 3. Secondary halos of dispersion of vanadium and titanium.

distribution, which is directly related to increased concentrations of platinum in the occurring under abnormalities of bedrock.

\subsection{Nickel and cobalt}

Among other rare elements, nickel and cobalt are distinguished by increased concentrations and contrasting anomalies (Figure 2). The positive anomalies of nickel and cobalt are partially spatially combined with the anomalies of platinum, but they are more widespread, while the promising positive anomalies of platinum $(>0.1 \mathrm{ppm})$ are characterized by a clear spatial confinement to the zones of vein rock development in the dunites of the Vysotsky ore occurrence.

A positive chromium anomaly is observed throughout the entire area of the ore occurrence, extending over more than $1.5 \mathrm{~km}$ in length with an average width of $400 \mathrm{~m}$.

Anomalies of manganese within the Vysotsky ore occurrence are weakly manifested and small in size (no more than $300 \mathrm{~m}$ in width and 200 to $400 \mathrm{~m}$ in length), all observed anomalies are elongated in the submeridional direction. In the northern part of the ore occurrence, several close anomalies are observed (Pilyugin et al., 2015).

\subsection{Vanadium and titanium}

Vanadium and titanium (Figure 3 ) is characterized by positive anomalies elongated in the submeridional direction. The association of the positive anomalies of vanadium to the 

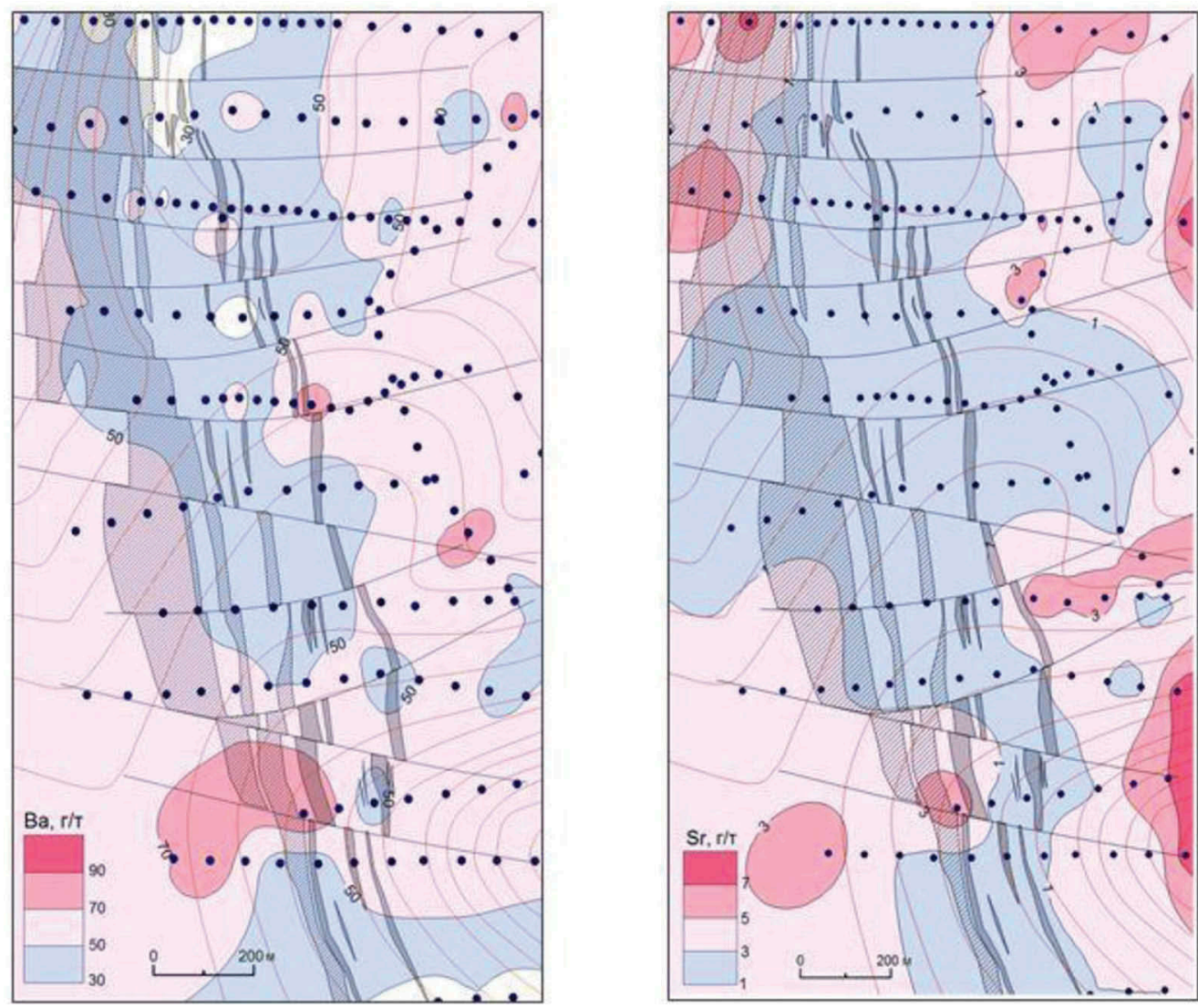

Figure 4. Secondary halos of dispersion of barium and strontium.

clinopyroxenite shell of the massif is noted, which is explained by the presence of vanadium in the composition of clinopyroxene (Lazarenkov et al., 2013).

Within the dunite core of the massif, the vanadium anomalies are less pronounced in the ore occurrence contour of the Vysotsky anomaly, but their confinement to dypsidite and gornblendite dikes is also noted.

\subsection{Barium and strontium}

Negative anomalies of barium and strontium spatially coincide with positive anomalies of platinum (Figure 4). Anomalies of barium are elongated in the submeridional direction, while there is a clear confinement of these anomalies to dikes of gornblendites and diopsides, but the reason for this is most likely the confinement of these concentrations to thick carbonate veins in the weathering crust of dunites, which in turn are confined to fracture zones at contacts by the rocks.

Negative anomalies of strontium are characterized by wider halos, while they are more manifested in the northern and central parts of the Vysotsky ore occurrence site.

Thus, in secondary scattering halos within the Vysotsky ore occurrence, positive anomalies of chromium, manganese, nickel and cobalt and negative anomalies of barium and strontium spatially coincide with positive anomalies of platinum and palladium. Anomalies of phosphorus, copper, zinc, lead and silver are less informative and cannot be used for search purposes. On the whole, the presence of sufficiently contrasting anomalies of chromium, manganese, nickel, and cobalt superimposed on each other allows us to recommend 
lithogeochemical surveys to refine, identify and predict the indigenous platinum mineralization within the Svetloborsky massif, as well as other poorly studied massifs of the Ural Platinum belt with the known the number of dike and vein rocks, such as Veresovoborsky, Kamenushinsky and others massifs.

To clarify the relationships between platinum and individual rare elements in the eluvialdeluvial deposits of the Svetloborsky massif for samples taken at the Vysotsky ore occurrence, we performed statistical processing of the data obtained, including correlation analysis and factor analysis using the principal component method. The source data array consists of 171 samples. When statistical processing of the results of testing with the contents of chemical elements in samples below the detection limit of the device were replaced by $1 / 2$ the detection limit. Since the contents of chemical elements are distributed lognormally, the prologarithmic values of the contents of elements were used for statistical analysis.

Based on the analysis of the matrix of correlation coefficients $(r=0.16,95 \%$ probability, 171 samples), the following conclusions can be drawn about the relationship between the contents of chemical elements in the secondary dispersion halos of the Vysotsky ore occurrence:

- platinum has significant positive correlation coefficients with palladium, chromium, manganese, nickel and cobalt and significant negative correlation with silver and barium;

- palladium, unlike platinum, has positive correlation with only chromium $(\mathrm{r}=0.18)$, nickel $(\mathrm{r}$ $=0.36)$, cobalt $(\mathrm{r}=0.55)$ and negative with silver $(\mathrm{r}=-0.25)$

Factor analysis carried out according to the logarithms of the contents of chemical elements in the overlying loose sediment massif allowed us to identify several elemental associations. Based on the results of factor analysis, we determined the main components of the indicator values, which were determined by the action of a particular factor, or a combination of both.

\section{CONCLUSIONS}

According to lithogeochemical surveys, the spatial distribution of anomalies of platinum and other rare metals, according to the results of correlation and factor analysis, the most informative from the point of view of searches for anomalies of platinum metals are data on $\mathrm{Cr}, \mathrm{Ni}$, $\mathrm{Co}, \mathrm{Mn}$, which can be considered indicator elements platinum-metal mineralization in eluvialdeluvial deposits of the Svetloborsky massif.

Thus, lithogeochemical surveys using secondary scattering halos are appropriate and can be recommended for other poorly studied massifs of the Platinum belt of the Urals with a developed platinum-dunite type of platinum-metal mineralization, for example, for Veresoborsky and Kamenushinskymassifs located a short distance from Svetloborsky massif.

The presence of secondary aureoles of platinum dispersion in the eluvial-deluvial deposits of the Svetloborsky massif serves as a reliable search sign of the indigenous platinum-metal mineralization.

1. Noble metal specialization in eluvial and deluvial-eluvial cover deposits monometallic platinum, inherited from indigenous sources.

2. In secondary scattering halos, the following associations of elements were distinguished: characteristic of dunites - $\mathrm{Pt}, \mathrm{Pd}, \mathrm{Cr}, \mathrm{Ni}, \mathrm{Co}, \mathrm{Mn}$, and characteristic of vein rocks - $\mathrm{V}$, Ti, $\mathrm{Cu}, \mathrm{Zn}, \mathrm{Pb}, \mathrm{Ba}, \mathrm{Sr}$.

3. It is noteworthy that the anomalies of individual elements are clearly confined to the areas of development of vein hornblendites and diopside rocks of the massif, as well as the anomalies of the elements themselves overlapping each other: within the Vysotsky ore occurrence, the positive anomalies of platinum and palladium spatially coincide with the positive anomalies of chromium, manganese, nickel and cobalt, as well as with negative anomalies of barium and strontium. Moreover, platinum has an average positive correlation coefficient with chromium, which indicates that platinum is associated not only with the platinum-chromite type of mineralization, but also with others. 
4. Peculiarities of the distribution of elements found in the secondary halo identified within the Vysotsky ore occurrence can be used in searches for platinum ore occurrences both within the Svetloborsky massif itself and in other zonal clinopyroxenite-dunite massifs of the Platinum-bearing belt of the Urals.

\section{REFERENCES}

Gayfutdinova A.M., Telegin Yu.M., \& Talovina I.V. 2015. Secondary dispersion halos of platinum group elements, gold and silver of the Svetloborsky dunite-clinopyroxenite massif, Platinum Belt of the Urals. Mining informational and analytical bulletin (1): 312-318.

Ivanov O.K. 1997. Concentrically-zoned pyroxenite-dunite massifs of the Urals, Ekaterinburg.

Lazarenkov V.G., Pilugin A.G., Vorontsova N.I. \& Talovina I.V. 2013. Rare earth elements in platinum bearing vein chromitites of Nizhni Tagil pyroxenite-dunite massif, Central Urals. Zapiski Gornogo instituta (200): 222-225.

Nikiforova V.S., Vorontsova N.I., Duryagina A.M. \& Talovina I.V. 2016. Vein rocks of the Svetloborsky massif and their petrochemical characteristics. Mining informational and analytical bulletin (2): 236-243.

Nikiforova V.S., Duryagina A.M., Telegin Yu.M. \& Talovina I.V. 2016. Rare elements in veined rocks of the Svetloborsky dunite-clinopyroxenite massif of the Ural Platinum Belt. Mining informational and analytical bulletin (2): 244-252.

Pilyugin A.G., Talovina I.V., Duryagina A.M. \& Nikiforova V.S. 2015. Geochemical features of platinum-bearing dunites of the Svetloborsky and Nizhny Tagil massifs of the Ural Platinum Belt. Zapiski Gornogo instituta (212): 50-61.

Tolstykh N.D, Kozlov A.P., Telegin Yu.M. 2015. Platinum mineralization of the Svetly bor and Nizhny Tagil intrusions, Ural Platinum belt. Ore Geology Reviews (67): 234-243.

Tolstykh N.D., Telegin Yu.M. \& Kozlov A.P. 2011. Platinum mineralization of the Svetloborsky and Kamenushinsky massifs (Urals Platinum belt). Russian Geology and Geophysics (6): 603-619. 